anthropology. In this connexion, however, Prof. R. C. Thurnwald's account of the profane literature of Buin, Solomon Islands, is even a more valuable pointer towards a method of gauging social values, while affording an index of change under contact with external influences. The songs which he collected, at first in 1908-9 and then in 1934, deal with topics of everyday life, and by their difference in manner and matter show unconsciously but infallibly how times have changed.

\section{Sodium Lamps for Lighting Tennis Courts}

For the lighting of tennis courts it is essential that there should be complete freedom from glare and that the light should have a high speed of discrimination. In Philips Technical Review (Eindhoven) of August last, it is pointed out that both these requirements are exceptionally well fulfilled by a lighting system employing sodium lamps. Although no satisfactory method has yet been found for making quantitative measurements of the disturbing effect produced with different types of light, experience has shown that the presence of a source of light in the field of vision is less disturbing with sodium lamps than with other lamp sources of equivalent total candle power. This is due to the comparatively low luminous intensity of sodium lamps. Several experimenters have also proved that the speed of discriminating objects is quicker with sodium light than with other types of light. The illumination of tennis courts is particularly important in regions with a tropical climate where the heat renders play during the day impossible, and where during the evening, when the atmosphere is cooler, darkness sets in very quickly. Three open-air tennis courts in the Netherlands East Indies were recently equipped with sodium lamps. Good results have been obtained with an arrangement of eight 150 watt sodium lamps arranged in two rows, containing four each, on the sides of the court and situated 20 feet above the ground.

\section{Phenology of 1935}

THE Phenological Report for 1935 by I. D. Margary (Quart. J. Met. Soc., 62, No. 265) covers the period December 1934-November 1935 inclusive. That period was of unusual interest on account of two spells of exceptional weather-the very wet December of 1934, and the bitterly cold period of May 1935 when a strong flow of air from polar regions brought severe frosts and snowstorms down even to the coastal regions of the south of England. The early months of 1935 were, on the whole, mild, with the result that in most counties flowers appeared early. The wintry weather in May therefore caused damage to plants and trees on a scale that luckily can probably be seen only once or twice in an average lifetime. Insects reacted eccentrically to this topsy-turvy weather that preceded the setting in of true summer weather, and showed very variable dates for their first appearance. Migrant birds behaved likewise; the species that normally arrive early were in the south mostly much in advance of their average first appearance; those that usually arrive late, for example, the garden warbler and the spotted flycatcher, were nearly all abnormally late. The spotted flycatcher was, however, exceptionally early in reaching the northern parts of Scotland and Ireland.

\section{Soviet Arctic Exploration}

IN continuance of its plans of Arctic exploration, the Soviet Government, according to the Soviet Union Year Book Press Service, is planning to dispatch ninety-five Arctic expeditions this year. Besides new geological prospecting work, topographical surveys in high latitudes will be combined with hydrographical work in the Kara and Laptev Seas. The northern rivers will also be studied with the view of improving transport. Research is also in hand on the problem of the northward extension of agriculture. Last year's work led to the discovery of coal deposits in the Chukchee peninsula, and these are now being worked.

\section{New Coastline of Antarctica}

THE Norwegian expedition to the Antarctic under Mr. L. Christensen which aims at mapping from the air the partially known coast-line of Antarctica between long. $100^{\circ} \mathrm{W}$. and $10^{\circ} \mathrm{E}$. is reported by The Times to have discovered one of the missing stretches of the coast. Mr. Wideroe, flying from the Thorshavn, found land between Queen Maud Land to the east and Princess Ragnhild Land to the west in about lat. $69^{\circ} 30^{\prime} \mathrm{S}$. and long. $38^{\circ} \mathrm{E}$. Even more interesting than this completion of the coast-line south of the Indian Ocean was the discovery by another flight of a mountain range extending westward for at least two hundred miles from lat. $71^{\circ} 30^{\prime}$ S. and long. $26^{\circ} \mathrm{E}$., with peaks rising to $6,000 \mathrm{ft}$. and $10,000 \mathrm{ft}$. This range would appear to lie in Princess Ragnhild Land and to extend into the new land. Farther east, it may be remembered that in 1930 Sir Douglas Mawson found mountain ranges in the interior of Enderby Land. In all probability, these ranges will prove to be fault ranges along the edge of the plateau of the eastern Antarctic.

\section{Presentation to Dr. E. J. Butler, F.R.S.}

For many years, mycologists throughout the world have reaped the benefits of the great work carried out by Dr. E. J. Butler, the first director of the Imperial Mycological Institute, Kew. Following upon his resignation, workers in all parts of Australia contributed to a presentation fund organized by Dr. W. L. Waterhouse of the University of Sydney. Acting on their behalf, the High Commissioner for the Commonwealth in London, Mr. S. M. Bruce, kindly consented to make the presentation, which took place at the Institute on February 8 in the presence of the members of the staff, most of whom had been with Dr. Butler throughout his term of office. One of the gifts was an inscribed table clock made of Australian woods.

\section{Biological Equipment}

Messrs. Griffin and Tatlock, Ltd., Kemble Street, Kingsway, London, W.C.2, have issued a catalogue, No. $30 K$, of biological and general 